\title{
Outside Caste? The Enclosure of Caste and Claims to Castelessness in India and the United Kingdom
}

\author{
DAVID MOSSE
}

Anthropology, SOAS, University of London

\section{IN T R O DUCTION}

Caste is ever-controversial, whether as a kind of identity, a social system, or the basis of discrimination. For nearly a century, scholars of caste have been caught in the crossfire of the politics of decolonization and of Dalit emancipation. Two Indian intellectuals stand out as having used anthropology and progressive law/ policy to shape modern knowledge on caste, knowledge that today is challenged by reactionary political deployment of postcolonial deconstructions of caste. The year 2016 marked the one hundredth birth anniversary of Professor M. N. Srinivas, who is celebrated as the man who founded and institutionalized Indian social anthropology as a fieldwork-based, comparative, and generalizing social science in its postcolonial form. It also marked the 125th birth anniversary of Dr. B. R. Ambedkar, a man who, more than any Indian national leader, mobilized a social and political, institutional, and legal response to social exclusion and injustice and put in place constitutional safeguards.

The lives of these two men are contrasting in some respects - the one was Brahmin and the other Dalit by caste, but they also mirror and parallel each other. Both exercised a kind of reverse anthropology, traveling to another society, the United States and England, respectively, in order deeply to

\footnotetext{
Acknowledgments: This article is based on the fifth M. N. Srinivas Memorial Lecture delivered at King's College, London on 29 November 2016, and the 2016 Ambedkar Lecture, University of Edinburgh. Gratitude, respectively, to the King's India Institute/Royal Anthropological Institute and the Centre for South Asian Studies, Edinburgh. The research was supported by grants from the ESRC (ES/H009051/1) and the UK Equalities and Human Rights Commission. I thank my collaborators on the latter project, Meena Dhanda and Annapurna Waughray, for editorial comments, and Murali Shanmugavelan, Rupa Viswanath, and the CSSH reviewers for incisive points. Thanks, too, to David Akin for helpful editorial advice. The views expressed in this article are those of the author and do not necessarily reflect those of other individuals or agencies involved or consulted in this research.
} 
immerse themselves in the culture, thought, and values of that society, grasping its essentials and seeing its flaws, and returned home seeking to know the workings of their own society beyond the metropolis, the middle-class, and the "book view" (Srinivas 1976: 164; Vajpeyi 2014). Both men lost their books, notes, and papers - Ambedkar to a German torpedo and Srinivas to a Stanford arsonist - but through lived experience discovered caste as the key mediator of human relations in India. In Rampura village, Srinivas discovered that he could not be other than a Brahman, and more significantly, Ambedkar back in India experienced painfully that despite every imaginable qualification he could not be other than an untouchable (Srinivas 1976: 164; Vajpeyi 2014).

Their imperatives were of course different. Ambedkar took his own humiliation as indicative of a social system whose "mechanisms, genesis and development," whose underlying beliefs and effects on millions of Dalits (members of castes subordinated as "untouchable") had to be understood in order to be challenged (Ambedkar 1979). Srinivas placed his emphasis on social scientific knowledge itself, on truthful observation and description of social patterns, functions, and change, through his roles as a mentor, institution builder, and, perhaps reluctantly, public intellectual. As Veena Das remarks, Srinivas was of the generation that "had to forge the idea of social science under the sign of the [independent] nation" (2000). This meant freeing anthropology from two things: its heritage as part of the colonial enterprise, ${ }^{1}$ and its nationalist self-representation derived from a textual view of Indian civilization (ibid.). Radcliff-Brown's structural functionalism and the practice of rigorous fieldwork served both purposes. As Srinivas demonstrated in his famous idea of "Sanskritization" (1995: 15-41), civilizational debate would be relocated within observed social processes such as competitive social mobility.

This article is about more recent reactions and political and policy challenges that work against both Ambedkar's drive to reveal caste as a fundamental fact of history and power, with harms countered through law and social policy, and Srinivas's idea of a postcolonial social anthropology of caste. While in the new transnational politics of caste Dalit organizations find recognition in the anthropology of caste and in legal protections with international scope, Hindu organizations have mounted political and epistemological challenges. On one hand, they have "enclosed" caste within religion and the nation, specifically Hinduism and India, so as to restrict the field of social policy and exempt caste from the law as a basis of discrimination. On the other, they have attempted rhetorically to re-embed social anthropology in its colonial past so as to dismiss "caste" as a category of description and social analysis. To make my points, I will employ the paired cases of caste among non-Hindus and caste outside India. In both, there is sufficient social-scientific

\footnotetext{
1 See Fuller (2016b; 2016a) for a reappraisal of this heritage.
} 
evidence that caste and its un-equalizing effects exist, and yet there is marked resistance to public recognition of this fact in social policy and law.

The first case is the Indian policy approach to Christian and Muslim Dalits and the denial to them of state provisions and protections as Scheduled Castes (historical victims of oppression and untouchability). The second is resistance by Hindu organizations to the implementation of legislation outlawing castebased discrimination in the UK. Both cases show how, in an influential discourse, caste is enclosed within religion and internalized to Hinduism and the Indian nation. The intent is to both delimit legal and public action on caste and to discredit anthropological description. These examples will tell us something about caste as an aspect of "the postcolonial character of India's contemporary predicament," as Dirks (2001: 294) put it, and its diasporic manifestation, in the sense of an echoing tension between the liberal critique of traditional oppression and the nationalist critique of colonial intrusion. This tension produces competing frameworks of analysis that, as I will show, are today being folded in new ways into the strategies of social actors in fields of political contention.

These claims to castelessness - the denial of caste to non-Hindus in India, and the denial of the idea of caste by Hindu groups in the UK - will comprise the first two parts of this article. In the third and final part I will turn to other claims to castelessness in India today, first by the privileged who invest in the idea of a casteless world of middle-class merit, and second by Dalits in an area of my own fieldwork, who respond to being inescapably marked by caste with a different idea of life outside of caste. I turn first to the question of caste and non-Hindus in India, with the proviso that in all that follows what goes under the label "caste" must be unearthed in each historical and social context.

\section{CASTE ENCLOSED WITHIN HINDUISM}

In March 2015, the Bharatiya Janata Party (BJP) government of India decidedly opposed the demand for Christian and Muslim Dalits to have the status of Scheduled Castes (alongside Hindu Dalits), with all the state welfare measures and legal protections that this status entails. In doing so, it underscored the views, first, that "' untouchability' is a peculiar aspect of Hindu religion that 'denied to disadvantaged castes the fundamentals of human dignity..." (Ghildiyal 2015) and, second, that religious conversion (or rather specifically conversion to Christianity or Islam) changes the social identity of Dalits so as to free them from caste. Leaving aside the subsequent exceptions granted to Sikhs, Buddhists, and Jains as Indic religionists, this simply restated the position of the Presidential Order of 1950, which determined that "no person who professes a religion different from Hinduism shall be deemed to be a member of the Scheduled Castes."2

\footnotetext{
2 The list, or "schedule" of the Indian Constitutional (Scheduled Castes) Order of 1950 was itself substantially based on that drawn up by Census Commissioner (and anthropologist) J. H. Hutton for
} 
In the case of Dalit Christians, for the past fifty years church leaders and activists have objected to this as unconstitutional religious discrimination. They have done so on the unhappy but certain grounds that it can "be shown that [Dalits] suffer from a comparable depth of social and economic disabilities and cultural and educational backwardness and similar levels of degradation within the Christian community necessitating intervention of the State under the provisions of the Constitution." This quotes what the Supreme Court stated had to be proven to win a case, when ruling on a 1985 writ petition relating to a Christian cobbler in Chennai, Soosai, who was denied access to a central government scheme providing sidewalk work stations to Scheduled Castes. ${ }^{3}$

Indeed, the expansive Ranganath Misra Commission, which in 2009 reported the established fact of continuing discrimination against Dalit Christians and Muslims, concluded, "The caste system should be recognised as a general social characteristic of ... Indian society as a whole, without questioning whether the philosophy and teachings of any particular religion recognize it or not" (Ministry of Minority Affairs 2009: 153-54). Its recommendation that Christians and Muslims of equivalent caste should be included in the Scheduled Caste list is the one the BJP government decidedly rejected in 2015 .

The government here presumed that religious identity determines other identities, especially caste, and took as real the separate "imagined community" of Christians which the churches claimed but as a matter of historical fact had failed to produce (see Mosse 2012). This left Dalits who are Christian with the dilemma that, while in social reality dominant-caste others block them (especially in villages) from asserting themselves as people other than as defined by their birth and lineage - that is, as "untouchables" - the state allows them to be nothing but Christian (Krishnan 2011), thereby disqualifying them from statutory welfare and protection. The state requires that caste be an aspect of religious identity and practice and precludes recognition of caste in Ambedkar or Srinivas's terms, as the underlying system of social (and economic) organization.

When the Indian state privileges religion over caste, we are not dealing with a simple case of governing religious diversity, and the category "Hindu" that admits caste identities is not a straightforward religious identity alongside others. "Hindu" is a default identity that includes all those not

\footnotetext{
the British government's equivalent order of 1936, and likewise restricted to Hindus and treating caste disadvantage as ritual pollution (see also Waughray 2010). The schedule is available at: http://socialjustice.nic.in/writereaddata/UploadFile/CONSTITUTION\%20(SC)\%20ORDER\% 201950\%20dated\%2010081950.pdf (accessed 10 July 2018).

3 Soosai v. Union of India 1985, S.C C. supplement 590, https://indiankanoon.org/doc/1724190/ (accessed 10 June 2018). The arguments in this article on religion, Christianity, and caste in India draw on my fuller treatment of them elsewhere (Mosse 2012; 2018b).
} 
specifically affiliated to religions such as Christianity and Islam. Certainly, demarcating the Scheduled Castes draws distinctions between those religions that are "internal" to the national society and caste (Hinduism, Buddhism, Sikhism, Jainism) and those which are "external" (Christianity and Islam). Christians and Muslims are not simply adherents to separate religions (as Buddhists or Sikhs might also be) but are distinctively removed from the matrix of Indian society, which is essentially Hindu. The implication that national society is Hindu is explicit in the political ideology if Hindutva (Tejani 2008).

There are several implications, as Nathaniel Roberts argues (2016). First, since in a "pervasive elite consensus" being Hindu is a kind of divinely mandated ethnic heritage, one cannot speak of conversion to Hinduism. The "Hinduization" of Dalits or Adivasis is rather a matter of reintegration into the nation, construed by Hindu nationalists as ghar wapsi, or "homecoming." Second, because Hindu religion is foundational to social life, then as a matter of normative assumption rather than empirical fact conversion to Islam or Christianity (especially by Dalits) is taken to rupture relations and alienate people. It is seen as potential threat to public order and subject to external manipulation and force, and as such as requiring regulation by law. Anticonversion legislation was enacted in seven Indian states between 1967 and 2006. These laws scrutinize the authenticity of belief and the spiritual and material motivations of Dalits presumed incapable of "genuine conversion," in a manner that is entirely inapplicable to programs of Hinduization (ibid.: 114 , et seq).

Contrary to the discourse that encloses caste within Hinduism, my ethnographic and historical research over the past thirty years in Hindu and Christian rural Tamil Nadu convinces me that, there, caste has never been understood as Hindu (Mosse 2012). Which gods people worship and in what manner, the powers they believe determine good or ill fortune, and the affiliation to gurus, priests, or pastors are not at all fundamental to indentities of caste, or even to cultural values, as is widely presumed. This presumption is found not just in Hindu nationalist thought, Roberts points out, but also in the modern Western social science idea of religion as culture, value, and identity, upon which this Hindu nationalist thought rests (2016: 118-19). Christianity in the Tamil countryside, whether Catholic, Protestant, or Pentecostal, has never (even now, despite engagement in increasingly global forms) constituted a cultural boundary separating its adherents from Indian caste society. Dalit Christian activism, mass rebellion in the churches or exodus to less hierarchical Pentecostalism or Islam, and the rise of Dalit theology are all testament to a caste dynamic in Indian Christianity (Mosse 2012).

The question is, how did caste come to be enclosed in Hindu religion and with what effects? The answer, we discover, is bound up historically with the question of the religious identity of Dalits. Specifically, the idea that those who convert to Islam or Christianity are "leaving the fold" and weakening the ties of 
the nation rests on the supposed prior common identity of Dalits as Hindus. However, the "Hinduization" of Dalits has come to be regarded as an historically contingent outcome of distinct but interdependent processes of the late nineteenth and early twentieth centuries, driven by the struggles and political assertions of subjugated Dalits intersecting with discourses and exigencies of Protestant missionaries, the British administration, and, later, nationalists. These interactions reconfigured religion and caste into their modern relationship.

In her book The Pariah Problem (2014), Rupa Viswanath shows that before the late nineteenth century, in South India the idea that caste Hindus and "Pariahs" (as Dalits were known) shared religion was hardly accepted. "It was," she writes, "common for Pariahs to address caste folk as Hindus, a term used in contradistinction to themselves" (ibid.: 134). Well into the twentieth century, the term "Hindu" applied to "upper" castes of any religion. So, when in 1936 upper-caste Catholics in Thiruchirappalli (Tamilnadu) appealed to the colonial authorities against the bishop's decision to allow Dalits access to the main church building for mass, they did so as Hindus. They argued that it would contravene their established custom as "Hindu Christians of caste" if they were forced to sit next to a body of Adi Dravidas (Dalits) "composed solely of scavengers and cobblers and flayers."4

Viswanath (2014) gives historical depth to what is clear in the ethnographic record, namely that Dalits were an excluded section of society subject to enforced landlessness and agrestic servitude/slavery. They were a constitutive "outside," so that the spaces of society that counted as the village (the Tamil $\bar{u} r$ ), the public/common, or the Hindu presumed the exclusion of Dalits. And the public rituals of temple, tank, or village enacted Dalit exclusion or subordination, further articulated in ideologies of impurity and untouchability (Mosse 2012). Prior to the Hinduization of the Dalit plight, no caste person was in the least concerned about their religion, if indeed they were regarded as capable of religion at all (Roberts 2016: 145-46). Roberts points out that when British census takers used mutually exclusive religious categories (Hindu, Muslim, and so on) to sort these people, they departed from the more usual practice of distinguishing "clean" from servile castes (regardless of forms of worship), or Hindus from untouchables, such that late nineteenth-century native census workers had to be persuaded to record those barred from temple entry - the Dalits - as Hindus. (In significant contrast, the Brahmin census takers whom Joel Lee accompanied in his ethnography of the 2011 Census, recorded Dalits as Hindu "even when they themselves told him they were not" (Lee 2015: 3-5, cited in Roberts 2016: 127). ${ }^{5}$

\footnotetext{
4 Report of the trial "Plaint of a Parishioner against the Bishop," July 1936, Tiruchirappalli. Jesuit Archives, Vanves, France (cited in Manickam 2001: 366).

5 This glosses over the debate among British officials, not just on whether the Untouchable Scheduled Castes could or could not be considered Hindu by default, but also on related
} 
Moreover, the mass adoption of Christianity among Dalits across South India from the $1870 \mathrm{~s}$ is not properly understood as a movement of religious conversion in the sense of leaving the Hindu fold, but rather, Viswanath (2014) argues, as the forming of a "Pariah-missionary alliance" in the context of antagonistic relationships between enslaved laborers and landlords. This was mostly initiated by the Dalits rather than the missionaries, who were themselves just as disconcerted to be solicited by groups they had largely overlooked as to be overlooked by the elite groups they had sought to influence. In fact, for the most part missionaries of all denominations were conservative and sought, as one put it, to "raise [the Pariah] in his social state, not out of it."6 Historical research shows that Dalits were drawn to missionaries and the Christianity they preached for complex, overlapping material, social, moral, and spiritual reasons (e.g., Mohan 2015) and because the colonial government offered little protection from abuse. The government held a view of rural servitude as a benign moral economy (anthropologically reinvented as the jajmani system), maintaining a self-interested denial of the existence of slavery in the native labor regimes upon which both rule and revenue rested (Viswanath 2014). Protestant missionaries, on the other hand, intervened against relations of slavery, for example by enabling Dalit freedom from debt bondage, their acquisition of house sites, or their resettlement on agricultural "wasteland." But, Viswanath (2014) convincingly argues, in order to avoid the accusation from both home supporters and critics that their converts were materially motivated "rice Christians," they construed such evidently political-economic change as spiritual transformation, and Dalits as victims of "spiritual slavery" within a Hindu religious system. This even though the distinction between the material and the spiritual would have meant little to Dalits themselves. ${ }^{7}$

matters, such as what sort of a phenomenon caste was, or was perceived to be by people themselves (and it might be several, to do with religion or occupation, varna, title, rank or race, system or value); how distinct identities - caste, sub-caste, clan, tribe - could be tabulated; and whether the Scheduled Castes could be considered a distinct category in pan-Indian society and, if so, by what criteria or test. Colonial anthropology failed to resolve the latter question, bequeathing diversity to the "schedules" drawn up in 1936 (Fuller 2016b). However, these caste and religious categories were rendered simplified and self-enforcing by the exigencies of competitive representational politics, with proposed separate Hindu, Muslim, and Scheduled Caste electorates/reserved seats. "Untouchability" was narrowed to religious matters of temple exclusion and pollution - or in Ambedkar's terms the "social odium" suffered on account of Hindu dogmadefining the Depressed Classes or Scheduled Castes (ibid.), who subsequently became an increasingly identifiable and self-aware social and political category.

6 Rev. J. M., “Our Native Christians," Harvest Field (1863-1864): 203, cited in Viswanath (2013: 132).

7 The nature of late nineteenth-century Dalit "conversions" is a matter of unresolved historical debate. My intention here is not to emphasize the material over the moral or the spiritual. Both being drivers for economic freedom and human dignity, missionary-directed religious or lifestyle changes and Dalit social-spiritual aspirations intersected. Christianity entered Dalit struggles against a form of enslavement that was inseparably material and religious, and experienced in a world that did not 
The missionary logic that rendered caste and Dalit oppression a matter of spirit and religion then acquired further significance. In 1859, the British adopted a governing principle of non-interference in matters understood as "native religion," which administrators increasingly took to include caste. This also gave landlords a new language with which to resist and object to missionary interventions on behalf of their dependent laborers, namely that by doing so they were interfering in customary and religious practice. This was solidified in the courts through which, in effect, landlords obtained from the state a religious right to dominate and exclude Dalits (ibid.), whose claims were consequently invalidated. As Viswanath sums it up, "Religion emerged as the favored language of contestation" (2014: 143) and the judgement on missionaries shifted: once branded a threat to caste privilege because they abetted Dalit insubordination, they were now said to menace the Hindu religion and its social system because they contrived inauthentic conversions (2014: 163-67). ${ }^{8}$

However, this narrative of the threat of religious conversion only gained force nationally (beyond local conflicts) starting in the 1930s, again in response to Dalit assertions, but now in the context of the representative Legislative Councils (another tactic of British governance) and the new politics of identity demographics. Roberts (2016) places M. K. Gandhi at the very center of a project to incorporate Dalits as Hindu. This was aimed significantly as a defense against Dr Ambedkar's movement identifying Untouchables or Depressed Classes as a separate element in the nation-a recognized minority - with separate interests and constituting a separate electorate on the basis of their caste and economic oppression; that is, as those treated as outsiders and without natural alignment to the upper-caste Hindu nationalist leadership. Paradoxically, Gandhi sought to claim Dalits as Hindu by making ritual untouchability definitive of Dalits and as a distinctively Hindu form of humiliation. This effectively replaced the unfree labor and socio-economic oppression of Dalits with theories of pollution, and Ambedkar's political empowerment and land reform with symbolic remedies.

Ambedkar was himself clear that the oppression of caste could not be treated as a religious matter separate from society and economy. It is well known how critical he was of the Hindu scriptural sanction of caste and varna, but he rejected the idea that untouchability was only a cultural or religious matter. He was offended when the British colonial government refused to address what were clearly civic disabilities, such as Dalit children being

yet draw the modern distinction that missionaries deployed between the "religious" and the "secular" (see Mosse 2012).

${ }^{8}$ In parallel, 1901 Census Commissioner Herbert Risley underlined a view of caste as social/ ritual precedence, rather than hereditary occupation, using Brahmanical criteria, and thus "as distinctly, or even uniquely, Hindu-cum-Indian" (Fuller 2016a: 235). 
refused entry to schools on the grounds that the government could not intervene in matters of cultural or religious tradition. He proclaimed that Dalits held civic rights and the universal right to equal treatment and so he was equally offended by the Hindu reformers who felt that welfare work for Dalits was, as Gandhi put it, "a penance which the Hindus have to do for the sin of Untouchability" (Rodrigues 2002: 351-68).

Making Hindu reform the sole means of recovery of selfhood and identity, as Gandhi proposed, involved two internalizing effects. First, as noted, Dalits would be integrated into the nation by defining them first and foremost by their ritual impurity - their untouchability - which was a condition specific and internal to Hinduism. Second, this in turn made other remedies, including the social actions of missionaries, illegitimate intrusions into the internal affairs of the person and of Hinduism (Roberts 2016: 7, 143).

From this historical moment, Roberts argues, arose the currently pervasive (Indian and diaspora) elite consensus on caste, nation, and religious conversion. Conversion is interpreted as a form of self-alienation and betrayal of one's ancestors, and the religious affiliation and the souls of Dalits endure as matters of national concern. But equally, because of this nationalist discourse, conversion itself has acquired the novel capacity to symbolize culpable alienation by the state, and thus it can be used as a political strategy, as in the well-known Dalit mass conversions to Islam in the southern Tamil village of Meenakshipuram in 1981 (Mosse 2012: 191-93).

In sum, the conditions of British colonial rule, missionary practice, and Indian nationalist discourse together produce a powerful policy-framing of caste as exclusively Hindu (and Indian) that is quite at odds with empirical evidence. This has shaped the politics of conversion and the policy on Scheduled Castes defined by historical disabilities of Hinduism in a manner that marginalizes attention to caste as a continuing structural cause of poverty, inequality, and discrimination, and places caste outside the purview of the mainstream economic and development planning of the secular state. ${ }^{9}$ I have discussed these themes elsewhere (Mosse 2018a; n.d.). What I turn to now is

\footnotetext{
${ }^{9}$ One of my reviewers felt the argument on the elite historical construction of caste as religious and Hindu overlooked the centuries-long, and contemporary, Dalit critique of Brahmanic/Hindu caste ideology and exclusion. A clarification is required. Through a variety of philosophical/theological traditions, collective actions, and movements, Dalits have indeed raised voices against the ritual subordinations, humiliations, and exclusions of Hindu temples, sects, or priestly services that served to define enslaved Dalits as a polluting exterior. On these grounds, several Dalit leaders, including Ambedkar, rejected Hinduism and asserted their essentially non-Hindu identity; even though, as contemporary Dalit writer Raj Gauthaman maintains, Dalit protest culture must be forged through the medium of the Hinduism it opposes, and from which it draws its weapons (2011: 157). Such leaders did not, however, consider themselves exploited as Hindus, but rather as excluded "untouchables." This is different from, and in fact the reverse of, the modern Hindu nationalist incorporation of Dalits as Hindus with debilities defined and remedied in religious/cultural terms, which denies them legitimate political-economic claims or recourse to alternative nonHindu identities, including Christian ones.
} 
a parallel effort to enclose caste within Hinduism, also in response to Ambedkarite Dalit mobilization against caste discrimination, but this time outside of India, in the UK.

\section{CASTE IN BRITAIN}

It is well known that when they leave India and live in countries like the UK, Dalits cannot simply shed their caste identification any more than they leave Hinduism in India, even though caste takes different and varied forms when it is recontextualized in the UK and is partly articulated through separate religious affiliations, such as Ravidassia or Valmiki. ${ }^{10}$ Caste prejudice, sometimes in the form of discrimination in employment, business, rental markets, or services (e.g., refusal of taxi rides), bullying in schools, and the demeaning use of caste names have all been documented in independent academic and UK government-commissioned research. ${ }^{11}$ Cases of discrimination are also reported in health services and social care, such as when a social services careworker, having seen a picture of Guru Ravidass in the bedroom of an elderly Punjabi woman, refused to help bathe her (Metcalf and Rolfe 2010: 49, 74). Modern British-Asian youth music and culture has not been free from dominant

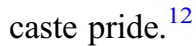

As with non-Hindus in India, in the UK there is no means to recognize and redress caste-based discrimination. This prompted a decade-long campaign for changes in the law, which drew together streams of activism led by Ambedkarite, Buddhist, Ravidassia, Valmiki, and other Dalit diaspora organizations. These included the UK Dalit Solidarity Network, the umbrella International Dalit Solidarity Network (IDSN), and India-based groups, especially the National Campaign for Dalit Human Rights (NCDHR). They also received support from Labour and Liberal Lords and MPs, including Jeremy Corbyn

\footnotetext{
10 Caste has diverse manifestations over time and context, so no assumptions are made here about the similarity of the experiences of those attributed, or claiming, caste identities equivalent to Dalit in rural/urban India and the UK. Readers are referred to a growing literature on caste associations (jati and allied grouping such as biradiri, zat) within different diaspora communities in the UK, and on attitudes toward caste as a matter of marriage, social belonging, family heritage, and ritual-religious assembly. For recent mapping and citations of this body of work in general, and separately in relation to UK Punjabis, Gujaratis, Sri Lankan Tamils and Nepalis, Sikhs and Hindus, see Dhanda, Waughray, et al. 2014; Takhar 2017; Dhanda 2017; Paramsothy 2018; Pariyar 2011; Vertovec 2000; Patel and Dhaliwal 2016; Nesbitt 1997; and Dhanda, Mosse, et al. 2014. Also, I do not intend the different approaches to caste in the Indian and UK legal systems to be discounted (see Waughray n.d.).

11 Studies focused on forms of caste pride or discrimination in different settings-regional, generational, and in fields covered by equality law-include: Anti-Caste Discrimination Alliance 2009; Dhanda 2015; 2017; Ghuman 2011; Metcalf and Rolfe 2010. Attitudes toward caste are nuanced and situation-specific, and vary by age and socio-religious, class, and caste identities. They are, moreover, shaped by the controversy over caste legislation itself. See discussion of the case of British Sikhs and Punjabi Dalits in Takhar 2017.

12 An example would be bhangra lyrics such as those that strengthen positive identification with Punjabi Jat (upper-caste) identity among Sikh youth (Takhar 2017, citing Mooney 2011: 311).
} 
(Waughray 2014). ${ }^{13}$ These campaigners brought the issue to the attention of Parliament which, to the surprise of many, voted to make caste-based discrimination illegal in the areas of work, education, and the supply of goods and services covered under equality law.

Thus was the Enterprise and Regulatory Reform Act, passed in April 2013. Section 97 of the Act requires government to introduce a statutory prohibition of caste discrimination into British equality law by making caste "an aspect of" the protected characteristic of race in the Equality Act of 2010. In light of this, the Equality and Human Rights Commission (EHRC) contracted a team of researchers, of which I was one (along with Annapurna Waughray and Meena Dhanda, who led), to help develop secondary legislation: (a) by undertaking socio-legal research on British equality law and caste to identify issues of principle, legal definition, exception, and public sector duty relevant to the implementation of this law (Dhanda, Waughray, et al. 2014); and (b) by conducting expert and stakeholder workshops to identify the range of experiences and opinions relevant to implementation (Dhanda, Mosse, et al. 2014). These studies took place in late 2013.

Nevertheless, the scheduled formal consultation on implementation of the law that was supposed to follow did not take place. The legislation remained unimplemented by the Conservative government, which Hindu organizations strongly lobbied for its repeal. In July 2018, the government responded to a public consultation, not on implementation but on whether legislative change is needed at all, or whether instead case law can be relied upon to protect against caste discrimination, taken as an aspect of ethnic identity under existing equality law. ${ }^{14}$ In its response, the government tabulated and interpreted the over sixteen thousand submitted statements (many of them identical "batch" responses) as grounds on which to reject the introduction of caste as an aspect of race in the Equality Act and to repeal the established duty to do so (Government Equality Office 2018).

Many aspects and factors in this stalled legislative process are of interest, but I am concerned here with just one crucial one, namely the public response of Hindu organizations to the proposed legislation, because I see it as a parallel case of the enclosure of caste within religion. In brief, a position strongly opposing new legislation was taken by Hindu organizations, including the Alliance of Hindu Organizations, Hindu Forum of Britain, Hindu Council UK, the National Council of Hindu Temples (NCHT), the Hindu Lawyers’ Association,

\footnotetext{
13 The mobilization against discrimination by these Dalit diaspora and Dalit rights organizations is a separate subject of research (see Waughray n.d.).

14 The instance that alerted the government to this possibility was an Employment Appeal Tribunal in September of 2015 (Tirkey $v$ Chandhok), which ruled in favor of a claim against abusive and discriminatory treatment of an Indian-national domestic worker in the UK, who identified as "Christian Adivasi" or "tribal," on the grounds of her ethnic origins, "including her perceived status in the caste system" (Waughray and Dhanda 2016: 186).
} 
and the National Council of Hindu Priests. I will refer here to their published or publicly stated views, and those of certain individuals, in short hand, as the "Hindu position." This position held, first, that legislation is unnecessary because caste discrimination does not exist, and second that legislation and public debate on caste produces prejudice against the Hindu religious minority in Britain. ${ }^{15}$

I will not discuss here the claim that caste discrimination does not exist (see notes 10 and 11). Suffice it to say that at the stakeholder workshop we organized, this was not a claim that could be sustained face-to-face with Dalits reporting their personal experience. As an instance of the second claim, on anti-Hindu prejudice, on 20 March 2014 the Alliance of Hindu Organizations (AHO) wrote to the Chair of the All Party Parliamentary Group on British Hindus to call the EHRC report (which itself rejected the idea of caste as inherently religious or Hindu) "overtly prejudiced against the British Hindu community," and charge that it was publicly funded research carried out "at the expense of the reputation and harmony of the British Hindu community." Beyond this, the letter claimed that "caste" itself is a "negatively charged and inherently racist word," and its use in British legislation "an act of antiHindu racial and religious violence and prejudice of the highest order."16

This present-day discursive enclosure of caste within Hinduism in the trope of "Hindu hurt," I will suggest, occurs in two distinct moves that I will treat in turn. The first is an "externalization" of caste (as a misrepresenting, "racist" idea) onto specific others. The second is the "internalization" of caste (jati) as a uniquely Hindu form of association that outsiders cannot legitimately represent or govern.

\section{The Externalization of Caste}

How is caste externalized as a racist misrepresentation? UK Hindu organizations have given their signature to a position that has appeared in a series of online articles, blogs, and recently a book (Shah 2015) in which Prakash

\footnotetext{
15 The voices polarized on caste legislation are not drawn from the same diaspora populations. For example, at the EHRC stakeholder event a majority of pro-legislation, Dalit organizations (fifteen, or 75 percent) were Punjabi (Dhanda 2017: 62); Hindu organizations opposing caste were significantly Gujarati. The position of Sikh organizations was more complex, but they strongly opposed any identification of caste with Sikhism (Dhanda, Waughray, et al. 2014; Takhar 2017).

${ }^{16}$ Letter from Vivek Sharma to Rt. Hon. Bob Blackman, Chair APPG for British Hindus on behalf of the Alliance of Hindu Organisations (AHO), 19 Mar. 2014, Subject: Response to EHRC Report on Caste Prejudice in the UK, http://www.mycasteishindu.org/index.php/component/content/article/20-frontpage/319-aho-briefing-for-appg-20th-march-2014 (accessed 17 July 2015). Consistent with this refusal of the language of caste, 3,588 respondents to the government's 2017 consultation rejected both legislative change and reliance on case law as protection against caste discrimination, since caste, and this discrimination, they said, does not exist in the UK. Some insisted that the word caste should be removed from domestic law, including case law, to "prevent the possibility of caste being a legal concept in domestic law" (Government Equality Office 2018: 13).
} 
Shah (legal academic and co-director of the newly formed Dharmic Ideas Policy Foundation) states that the proposed UK legislation on caste discrimination, the public debate, and the concept "caste" itself represents an orientalist-theological form of knowledge about, or a framework interpreting, Indian institutions that originated in the twinned purposes of colonial domination and rule, and the moral denigration of Hinduism by missionaries in the service of proselytism. The argument was subsequently polemicized in a report from the National Council for Hindu Temples titled "Caste, Conversion and a "Thoroughly Colonial Conspiracy", (NCHT-UK 2017), which describes UK legislation on caste discrimination as a "hate crime against Hindus."

Unsurprisingly, Shah and the NCHT are not much interested in what mainstream social science or historical research reveals about caste, or the various colonial and contemporary forces shaping its modern forms and effects. Their concern is to explain and discredit the link between caste and inequality, hierarchy, and discrimination. These alleged links, they argue, are fabrications produced by the imposition of Western normative ethics onto Indian cultural ideas-varna, jati, biradiri-that were mistranslated and derogated as "caste" (Shah 2015: 72). In this view, it is not the Dalit experience of discrimination that motivates the introduction of "caste" into UK equality law. Instead, "Dalit/untouchable" is portrayed as a false category produced by Anglican-colonial policies that criminalized certain caste/tribe identities (NCHT-UK 2017: 17-18). ${ }^{17}$ It is a persisting (missionary-colonial) cultural imaginary that vilifies Hindus and unnecessarily exposes them to litigation under the presumption that they practice caste discrimination. Because it is bolted to this colonialist moral evaluation, the language of caste, especially if built into law, is offensive to British Hindus.

In more direct terms, General Secretary, National Council of Hindu Temples Satish K. Sharma wrote in an open letter in 2015:

For the avoidance of any doubt, we re-iterate that the fluid and equitable, Dharmic, nonhereditary, non-endogamous, social structures which are repeatedly detailed in Hindu, Sikh and Jain scriptures, in no way match the Caste system which was created by the despotic medieval Popes in Europe, then exported by colonial missionaries to the Empire. It is ironic that this same concept is nowadays so favoured by its philosophical parents, the Evangelicals, as the "bête noir" with which to globally denigrate the Dharmic communities ... the legislation ... is tantamount to religious persecution of Hindus, Sikhs \& Jains and is in breach of the human rights of the minority Dharmic communities. $^{18}$

\footnotetext{
17 Reference here is to the Criminal Tribes Act of 1871 , by which entire groups of forest dwellers, itinerant traders, or those involved in protection/policing_-but not generally those subordinated as "untouchables"-were classified and regulated as hereditary criminals (Dirks 2001: 181-88).

${ }^{18}$ Letter dated 3 May 2015, posted on www.nchtuk.org ahead of the UK general election in 2015 appealing to "Dharmic voters" to vote for the Conservatives in favor of repealing caste legislation. It was subsequently removed from the website.
} 
In short, those who now constitute themselves as representatives of the UK's "Dharmic communities" (a term that embraces Hindu, Jain, and Sikh) regard "caste" as a mistaken and offensive category of description; individual qualities/attributes or the various types of association or marriage in Hindu society have been "maliciously transmuted" (NCHT-UK 2017: 23) into the social-categorical terms of caste, and manifestations of "sex- and love-based violence" have been misconstrued as caste atrocity. Further, the Hindu position sees in the proposed legislation the missionary-colonial idea of caste continued today as a project to regulate and control the Hindu religious minority in the UK. ${ }^{19}$

We have moved here from historically based representations of caste as Hindu to the modern Hindu objection to "caste" as an object at all. A social science idea of caste is delegitimized as racist and colonial and discourse on "caste" is enclosed within, or erased by, Hinduism, or the Hindu religious minority. This occurs through what Simpson (2016: 120) and others have argued is an intellectual project of the Hindu right to "shift the basis of ethical judgements, [and] insert the trope of 'Hindu hurt' within British politics and reconfigure the nature of political identities" (Mukta 2000: 442). In doing this, Hindu organizations reference and deploy anti-Orientalist theories of the colonial invention of caste (e.g., Dirks 2001, in NCHT-UK 2017: 16) that help reframe the issue of social justice and equality in terms of the colonized and the colonizer. The terms of the debate have been turned; it is no longer about caste prejudice, but prejudice about caste. This shifts the target of attention away from Dalit experience itself toward Western or Christian ideology, recalling how earlier threats to caste order were transmuted into threats to Hindu religion abetted by missionaries in colonial South India.

If anti-discrimination legislation today is understood as an attack on a Hindu religious minority, it is certainly conceived as an attack by Christians. The prominence of Church figures, especially the former Anglican Bishop of Oxford, Lord Harries, who supported introduction of the caste discrimination provision into Parliament in 2010, not only affirms to Hindu organizations the presence of a theological imagination behind the caste legislation, but also allows discovery of a specific Christian purpose in it.

\footnotetext{
19 More recently, Shah (2017) questions these attempts to defend authentic ancient Hindu teaching (e.g., on varna qualities) that have been corrupted into the modern "caste system" by colonial rule. He dismisses such "constructivist" positions found, for example, in Dirks (2001) on caste, or others on Hinduism (Sontheimer and Kulke 2001). Instead, drawing on the writing of S. N. Balagangadhara (1994; 2012), he insists that both the caste system and Hinduism, its putative fount, are fabrications of Protestant theological polemics, which inform us about Western culture and its constructions of India but tell us nothing about Indian or diaspora realities themselves (see Sutton 2018). The claim is that the caste system does not exist outside of the Western experience of India, or its hegemonic projection as a "colonial consciousness" among present-day Indians (Fárek et al. 2017).
} 
So, in a further enclosure of caste in religion, it was later claimed that the ultimate purpose of the UK law relates not to caste at all, but instead to religious conversion. In this Hindu representation, the aim of having caste discrimination recognized outside India and beyond Hinduism (among members of any religion and in the UK's legal system) is to bring pressure to bear on the Indian government to extend its legal provisions for Scheduled Castes to the presently excluded Christian and Muslim Dalits so as to remove an obstacle to Dalit Christian conversion. The UK anti-discrimination legislation is thus portrayed as a threat to the (Hindu) religious exclusivity of caste in the service of Christian proselytism, which is aimed, in turn, at increasing the Christian (demographic) presence in India to serve Western (UK and United States) geopolitical interests and divide and weaken India (NCHT-UK 2017; Shah 2015). Church involvement in international campaigns on Dalit rights - in reality an historical consequence of the fact that Dalits form the majority in the Indian churches and continue to experience caste oppression-signals for Shah "transnational activism for proselytism," being the "key reason why caste has emerged in the discourse of the Churches, Dalit organisations, and Parliament" (2015: 83). ${ }^{20}$

The discursive transformation of caste into a matter of offended religious sentiment, through exteriorization as the product of the malevolent schemes of outsiders, is pretty much complete. The Hindu objection to UK public discussion of caste in fact extends beyond the law and the "very hostile and derogatory views about Hindus and Hindu faith" expressed in the House of Lords, to coverage the caste question receives in other publicly funded fora, for example the $\mathrm{BBC}$, which received formal complaints concerning how the topic is considered, defined, and debated on the network. ${ }^{21}$ When a conference on caste, inequality, and development for professionals, funders, and policy-makers was organized through the SOAS South Asia Institute in September 2015, its director received a letter from Prakash Shah as Co-Director of the Dharmic Ideas Policy Foundation that objected to its critical stance on caste and imputed a motive of proselytism to NGO co-organizers and SOAS's association with Christian-Orientalist UK caste legislation (through the EHRC research).

The proposition that anti-caste-discrimination legislation in the UK is a "continuing foreign interference in India's internal affairs" (Shah 2015: 83) is intriguing. The link to Indian reservations policy and proselytism is factually groundless, but what is interesting is how the UK caste-law debate has

20 See Mosse (2012) on the relationship between mass protest against caste in the Catholic Church and internationalized anti-caste Dalit activism.

${ }^{21}$ British Hindu Voice complained to Lord Tony Hall (29 Sept. 2014) regarding a Nihal BBC Asian Network program that discussed caste and the festival of Navaratri. See http://rajeev2004. blogspot.com/2014/09/fwd-formal-complaint-bbc-asian-network.html (accessed 19 June 2018). 
produced platforms both on-line and off-line, for Indian Hindu nationalism and its representatives. They provide the terms in which UK legislation is contested, such as the Christian conversion threat, and through which a global Hindu identity is articulated, emboldened by the election of Narendra Modi, figured as a leader of the global Hindu community — "a lion coming out to fight for Santhana Dharmic values." They are also giving this Hindu nationalist discourse a presence in British politics.

Thus, in the run-up to the UK general election in May 2015, through events such as a conference on "Dharma rising," 22 at which senior BJP MP Subramanian Swamy was keynote speaker, there was appeal to Dharmic voters to respond to the threat of caste legislation supported in the manifestos of Labour and the Liberal Democrats, who, as one statement put it, "if re-elected ... would effectively introduce a Caste system here in the UK (because that is what the [Bishop] Harries law is designed to initiate)."23 Public speeches realigned British Hindu political allegiances from long-term support for Labour in places such as Leicester, to David Cameron's Conservative party. The latter was now credited with building relationships with the Modi government, strengthening business links with India, putting forward a Gujarati Hindu candidate (and later a cabinet minister, Priti Patel), taking a stand on Kashmir, and erecting a statue of Gandhi in Parliament Square, all alongside the commitment to repeal the Hindu-denigrating legislation on caste discrimination. $^{24}$

The Dharma Sewa Purvapaksha (a forum for a common Hindu-Jain-Sikh political voice) produced a flyer picturing the word "caste" branded on the foreheads of a mother and child above the headline, "Why Dharmic Voters need to VOTE for a Conservative Govt.," and implied that under Labour "every parent and child living today and forever will be branded a casteist." ${ }^{25}$ The direct appeal to vote Conservative in the online open letter on the 3rd of May, four days ahead of the election, crossed a line and put the Leicester-based National Council of Hindu Temples into trouble with the Charity Commission. The appeal was removed from the website.

22 British Board of Hindu Scholars (BBHS) conference, "Dharma Rising," 4-6 Apr. 2015, in London, West Midlands, and Slough. See http://www.nchtuk.org/index.php/8-news/latest-news/ 407-dharma-rising-conference (accessed 10 July 2018).

23 Open letter from Satish K. Sharma, General Secretary, NCHT-UK, 3 May 2015. See Sam Burne James, "Commission Assesses Hindu Charity's Apparent Endorsement of the Conservative Party," Third Sector, 5 May 2015, https://www.thirdsector.co.uk/charity-commission-assesseshindu-charitys-apparent-endorsement-conservative-party/governance/article/1345819] (accessed 1 Sept. 2019).

${ }^{24}$ E.g., Kapil Dudakia on “The Political Hindu,” Apr. 2015, https://www.youtube.com/watch? $\mathrm{v}=$ RDi2k1JBITE (accessed 9 July 2018).

${ }^{25}$ At http://pattniconnection.com/Events/DharmicCommunity-UKGenElection2015-GoldDustVotes.html (accessed 10 July 2018). 
The Hindu organizations' response to an international mobilization of Dalit rights activism on the law thus brought an Indian Hindu-nationalist discourse into UK politics, including the frankly eccentric imagination of UK anticaste discrimination legislation as being all about driving Indian reservations policy and Christian religious conversion. Of course, articulating the issue of UK caste legislation in the Hindu nationalist terms of Christian conversion builds connections to powerful allies in India, whose invited voices have a salience in British politics which will no doubt only increase post-Brexit.

\section{The Internalization of Caste}

The discursive enclosure of caste within Hinduism occurs through two moves: the externalization just explained, but also an "internalization" that leaves caste a matter internal to Hindu religion and forms of association. In this respect, the EHRC study's insistence that caste (as jati) was not a Hindu associational form could not be entirely embraced. Let us turn, then, from the external representation of the legislation issue to reading its perceived internal effects.

For the sake of context, let me note that on the question of the impact of the caste legislation the EHRC report concluded, "Many experts and stakeholder groups saw [this] as having an overwhelmingly positive protective, preventative and educative effect, as well as empowering those who today feel discriminated and silenced. It was argued that anti-discrimination legislation would reduce the taboo surrounding caste, reduce discrimination and help bridge-building for community cohesion within Asian communities" (Dhanda, Mosse, et al. 2014: vii).

Hindu organizations, however, regarded the legislation as producing "untold harm to the associational and economic freedoms of ... South Asian communities." 26 They claimed the law would seek to ban such key groupbased religious events as the Navratri festival on the grounds of alleged caste discrimination, generate prejudice against South Asian employers, require the monitoring of caste (as a protected characteristic), or unleash vexatious caste discrimination cases. Shah (2015) details the case against the law. I cannot discuss these concerns here (see Waughray 2016), but all were eventualities considered, reviewed, and debated in the EHRC work on how the law that Parliament had already passed should be implemented, without being regarded as insurmountable obstacles. What I want to suggest here is that to make sense of the Hindu organizations' objections requires understanding that they arise from a social project of an altogether different kind from that of Dalit organizations. That is to say, first, that it is not about caste discrimination per se, but rather about identity formation and, in particular, protecting the space for a religious identity, as British Hindus or now Dharmic religionists

${ }^{26}$ Dharmic Ideas and Policy Foundation, https://dharmicideas.wordpress.com. 
(rather than British Asians). This is itself a product of the importance of religion as a "mediating discourse for state institutions" (Zavos 2015: 1) in the multi-ethnic UK, with its shifting mix of concerns about multiculturalism, community cohesion, and religious militancy (Knott 2009). Second, the objections represent a contest not only over law but also over the categories of description that social science offers to law and their perceived effects.

The notion of "caste" in public discussion and law seems potentially disruptive of the Hindu social project of identity-making. ${ }^{27}$ If, as John Zavos suggests, diaspora identity involves "identifications outside the national time/ space in order to live inside, with a difference" (2015, citing Clifford 1997: $251)$ then the characterization of that difference is crucial. The assertion of positive Hindu identity requires elimination of negative ascriptions, including caste, especially where caste already exists as a critical representation of Hinduism itself, and is also internally dividing, politically disruptive, and the very opposite of the kind of civic virtue British Hindus seek to promote through ideas such as socially responsible service (sewa), which Zavos (2015) sees folded into Big Society themes through which Hindus become model citizens in UK society.

But if caste and any link with Hindus is best forgotten, why mobilize so publicly and noisily on the caste question as Hindus? This suggests a different kind of argument - also from the diaspora literature - namely that public assertions of a unified Hindu tradition (expanded to a Dharmic community) are important or become so precisely because of the continuing significance of differentiated caste (named as jati) identities "as an indispensable part of the associational life of Indians in the United Kingdom" (Shah 2015: 77). In this view, caste is vital to family status, marriage, community leadership, temple organization, voluntary organizations, and business and other networks. Especially so among Hindu migrants from East Africa where, according to Vertovec, corporate caste groups had crystalized as associations for purposes of liaising with government authorities, as against, for instance, those from Trinidad, with its history of indentured labor that eroded caste (2000: 25-26; Zavos 2012).

But in the different circumstance of Britain, where religion provides the privileged means for public identity negotiation, the development of an ecumenical composite "British Hindu" community requires that caste/jati networking, while of continuing importance, is protected as an "inner" domain (in Chatterjee's [1993] terms) to which entry is guarded and which cannot be exposed to outsider regulation through legislation, for fear that, as the City Hindus Network put it at a 2013 event, "Community organisationsjati/gnati based groups - such as those many of us have been exposed to since

\footnotetext{
27 Paradoxically, the mobilization against legislative recognition of caste-divided Asian identity served to differentiate Hindu from "Asian" identity, through epithets such as "my caste is Hindu" (mycasteishindu.org).
} 
a young age may well find themselves acting illegally." 28 The anxiety thus comes as some are led to wonder whether it will always be possible for caste affiliation to be distinguished from caste discrimination, and as the language of law turns on the ambiguous boundary between the inner-private and the outer-public. Some Hindus would want to "hold on to the identity-conferring role of caste, but deny that it could work in law as an identifiable basis of discrimination" (Dhanda 2015: 40). Meanwhile, for those (of any caste but in this polarized debate, primarily the Dalits) potentially subject to discrimination or the exclusions and stigmatizing effects of invisible caste networks, the law allows recognition and redress.

The strength of feeling in this debate arises from the "constitutive" capacity of law-its ability to construct categories and shape self-conceptions. It is seen to be about how people make their own identities and those of others (as bearers of rights), including in the eye of the state (Merry 2012: 105). Law is expected to have an educational role but is also given an ideological role. It offers a public articulation of the social that some regard as restricting freedoms and others as enhancing them.

The proposed law was unable to inscribe particular identities (the naming of castes is no part of $\mathrm{it}^{29}$ ), and its purpose was to address discrimination and not to criminalize or remove caste. But it would have allowed an aspect of "community" hitherto of the "inner domain," reproduced while remaining invisible to the public eye, to become subject to public discussion, claims, and cases. The "looping" (Hacking 1996) social effects of the social science idea of caste (or the cultural stereotype, as Hindu organizations fear) being drawn into law and its cases is unknown. It would certainly be channeled by the social divides articulated, in anticipation, by the present controversy. But the question here is not so much about how law shapes social identities but who controls the legal sensibility that will be deployed in matters of caste in the UK. If caste as a set of ideas and practices is open to the law as a "distinct way of imagining the real" (Geertz 1983: 184), it falls to influences beyond the control of particular groups. Placing the caste idea in public is either an incursion into inner community spaces ${ }^{30}$ or, for those suffering invisible judgements about their worth, it is the "outing" of prejudice offering the guarantee of protection under law (as Ambedkar understood). The government's July 2018 decision to repeal its duty to include caste in UK equality law, on the grounds that this "risked promoting, creating or entrenching ideas of caste or heightening caste consciousness" (Government Equality Office 2018: 5),

\footnotetext{
28 At www.cityhinusnetwork.org.uk/caste-legislation-event (accessed 19 Apr. 2015).

29 The only legally-relevant caste identity is that deduced by a court as having been held by a perpetrator of caste discrimination regarding the identity of the victim.

${ }^{30}$ The further claim of Hindu organizations is that the law on caste embeds Christian theology, and that its judgements would be shaped by the stereotyping presumption "that Indians, and Hindus specifically, discriminate on grounds of caste" (Shah 2015: 73).
} 
bends toward the protection of upper-caste community spaces and away from those seeking protection from discrimination.

The effects of the new legislation and the degree of litigiousness around caste was always unknown (although suspected to be limited). This has been a meta-contest about who can allow or disallow the language of caste itself (Merry 2012: 105) at critical junctures, and derivatively about the categories of description, interpretation, and explanation of the social. These are epistemological struggles between claims and counterclaims to knowledge, and about being known or unknown.

As such, they are also a public engagement with social science, especially anthropology, as a generalizing discourse that makes the social available for public debate and for law; an engagement that places social groups in a very different relationship to that social science, which is in turn affected. Hindu organizations aim to detach their sociality and associations from anthropology and its category of caste, except where provincialized as a Western colonial or theological notion that is unintelligible to the society to which it is applied (Shah 2015: 24). By contrast, Dalits, in their struggle for justice, place their experiences in the hands of ever-more-generalizing frameworks: of caste, Christian or Buddhist social ethics, law, and human rights. As one would expect, these contentions have already changed the public discourse and meanings of caste in the UK.

In the simplest terms, we have here a historically-anticipated contest between claims to freedom from caste discrimination and claims to the freedom of caste association in the name of religion. This is linked internationally with the struggle for global freedom from caste versus the freedom of the Indian nation to resolve the question of caste as an internal matter, unique both in form and solution to India, as a postcolonial nation, and its social policy. In this regard, the Indian government has made stringent efforts, especially since the 1990s, to ensure that the issue and language of caste or caste-based discrimination does not enter the agenda of United Nations treaty bodies, ${ }^{31}$ and that India does not have monitored accountability to the UN for its record on caste inequality and discrimination (see Waughray 2010). In March 2016, a report on caste-based discrimination by the UN Human Rights Council Special Rapporteur (SR) on minority issues (Izsák-Ndiaye 2016) was objected to by the Indian Permanent Representative to the UN in Geneva as "in breach of the SR mandate," caste not being covered under issues of minorities - that is national, ethnic or religious minorities - even though Dalits, taking their cue from Ambedkar's historical struggle, were self-identifying as such (Mitra 2016; Waughray 2010). This is only the most recent of a series of stand-offs

\footnotetext{
${ }^{31}$ For example, caste as a form of discrimination based on "descent" under the International Convention for the Elimination of All Forms of Racial Discrimination (ICERD) (Waughray 2010: 335-36).
} 
following repeated efforts by Dalit and human rights organizations to internationalize the issue of caste in the legal language of race, descent, and human rights, most notably tabling the issue of caste discrimination at the 2001 World Conference Against Racism (WCAR) in Durban. These efforts have consistently been blocked by official representatives of the Indian government, who refused to agree to amendments that would allow caste to fall officially under the International Convention on the Elimination of All Forms of Racial Discrimination (ICERD) (Waughray and Keane 2017).

In sum, it is clear that the interlinked resistance to the language of caste in international law or in other jurisdictions such as the UK by the Indian government or Hindu organizations is a response to transnational campaigns on caste and Dalit rights that de-enclose or universalize caste. These efforts to domesticate caste parallel the enclosure of caste within Hinduism in the response to Ambedkar's movement in the 1930s, in the Indian policy erasure of caste outside Hinduism, and as a response to the introduction of caste into UK equality law.

\section{COMPETING CASTELESSNESS IN CONTEMPORARY INDIA}

I come now to a third and final set of claims to live "outside caste," which characterize the contemporary social life of caste in India. Claims to castelessness differ radically with social position, between upper-caste and Dalit. Today, the idea that caste is misconstrued as having to do with inequality, injustice, and discrimination, and need not (or no longer need) be regulated by law, is common among India's privileged castes and middle classes (e.g., Subramanian 2015). There is a rising tide of opinion against the policy of affirmative action "reservations" for lower castes in public sector employment and higher education, voiced in the name of merit, modernity, and market-led development. Thorat, Naik, and Tagade (2016) point out that the arguments against reservations on such grounds as poor outcomes, "creamy-layer" benefits, or inefficiency are simply not supported empirically, and a swell of recent economics research (reviewed in Mosse 2018a) clearly refutes the notion that affirmative action is no longer necessary because unequal opportunity and market-based discrimination are things of the past.

In India, the privileged critics of reservations do not usually denounced caste itself as colonialist theology, but they do understand it as having been transformed by forces of economic mobility and democracy, so that what remains of caste is benign or beneficial. Caste, as Balmurli Natrajan (2012) explains, is portrayed as a valued social asset or cultural identity, as part of the vitality of Indian democracy, or as providing networks of trust for business. In any case, caste is seen as a private family matter that should not be the subject of public policy and reported caste atrocities are identified as brutal abnormalities of normally benign caste (ibid.). Caste is stripped of its relationality, and therefore of the character of inequality or discrimination. Caste is enclosed, or internalized, as cultural belonging, apart from economy and 
society. In parallel, "castelessness" (the personal irrelevance of caste to all interactions) becomes an upper-caste subjectivity (Subramanian 2015: 295-96). But this "castelessness" is increasingly subject to critical appraisal as a powereffect, as cloaking upper-caste privilege and delegating, or exteriorizing, caste as a subaltern as much as a colonial formation. Dalits specifically are accused of being its purveyors (ibid.; Deshpande 2013: 32-36).

While scholars such as Andre Béteille, and Fuller and Narasimhan, whose book on Tamil Brahmans quotes him, say, "Caste has ceased to play an active part in the reproduction of inequality, at least at the upper levels of the social hierarchy" (2014: 121-22). It would be more accurate to say that caste only ceases to matter (with opportunity arising from individual merit) if one discounts all the class- and caste-based cultural capital, the networks, and language that people need to get to the point where caste does not count. It is unsurprising that those who benefit from opportunity-hoarding, the operation of "prejudicial norms" related to stereotyped (and perhaps feared) out-groups (Thorat, Naik, and Tagade 2016), and the "privileged capacity," as Deshpande (2013: 32) puts it, to translate accumulated "caste capital" into "modern capital" (property, higher qualifications, professions, etc.) would want the work of caste to be accomplished unnoticed, hidden behind self-fashioned fronts of casteless merit, modernity, and middle-classness.

Because of the way reservations policy works, Deshpande (2013: 36) points out, upper castes are guaranteed anonymity in preserving privilege born of caste, "encashed" as casteless merit. They can lay claim to private or public resources as unmarked citizens, without having to actually abandon caste. Meanwhile, lower castes become "hyper-visible" in their claims. Given that Dalits can only mobilize for rights or resources or justice by using caste politically (firmly identifying them with their caste), "castelessness" can be deployed against them in elite-dominated domains (ibid.: 32, 36).

As Subramanian (2015: 293) notes, these processes are relational. That is to say, upper-caste claims to middle-class meritocracy can be threatened by lower-caste political assertions that might expose the caste privilege behind "merit," undercutting general cultural, religious, or class identities by exposing caste. Threats to the caste-invisibility of privilege provoke resistance, as in, for example, the violent reaction to the extension of reservations to a broad category of the Other Backward Classes in the 1990s, which, Deshpande (2013: 38) argues, exposed the "general category" as essentially upper-caste, or as seen in the push-back against the reintroduction of caste enumeration into the national census in 2011 (Vithayathil 2018). And I have explained the response to the introduction of caste into UK equality law in terms of the threat to expose caste to public scrutiny and "brand" cosmopolitan Hindus with the caste label, while damaging their "incorporated" image in the UK "market of identities" (see Subramanian 2015: 314). At least in the UK, as Zavos puts it, "Hindu identity develops ... through dialogue with other 
diasporic identities" (2015: 2). At this juncture, the Dalit caste discrimination legislation movement is the "opposition" against which the Hindu (or Dharmic) community has sought institutional cohesiveness and new public articulation of its identity and political position.

\section{Dalit Aspirations to Castelessness}

I have given much attention to the perspective of caste-privileged groups, their enclosures of caste and claims to castelessness. In conclusion, I want to turn attention to contemporary attitudes to caste among Dalits, beginning with those expressed in an opinion survey of 204 individuals across age, gender, class, caste (Pallar, Paraiyar), and religion (Hindu and Christian) and covering issues of caste identity and relationships. It was carried out between 2005 and 2011 by my collaborator and Dalit resident of Alapuram village, M. Sivan, alongside my own fieldwork in two village sites of long-term research, in the southern Tamil district of Sivagangai. I also draw here on interviews recorded in the same communities by Jesuit Dalit activist Selvaraj Arulnathan, as part of a collaborative project (see Mosse 2018b).

The denial of caste among the privileged can be set against what appears, at least in a Dalit community that I am somewhat familiar with, to be an emerging aspiration to "castelessness" of a different kind. This is more akin to Dr Ambedkar's "annihilation of caste" and his idea of fraternity grounded in common humanity and, as he put it, the transformation of the "social conscience" (Rodrigues 2002: 122, 525).

I can only briefly summarize some key findings on the views and aspirations expressed by people across age, gender, or religious affiliation as Hindus, Catholics, Protestants, or Pentecostals (for details, see Mosse 2018b: 276-87). One finding is that these Dalits place the life of slavery, untouchability, and humiliation in the past and that civility and equality of treatment are on the rise. From earlier work in this locality I was aware of two socially distinguished kinds of response to historical and present caste subordination. The first was framed by a Dalit discourse of honor aimed at challenging exclusion and subordination in relation to public space, land, education, and religion, including within the Catholic Church. Another was aimed at inner transformation and a break with an untouchable past through forms of cultural reevaluation, re-mythologizing (including through Christian imagination), and the reshaping of service roles (Mosse 2012: 168-86). What seems clear is that there has been a marked weakening of the discourse of honor in tandem with socio-economic changes and the legally backed prohibition on practices of caste discrimination, or exclusion from public spaces such as streets, shops, tanks, and temples, as well as the Catholic Church.

Instead of emphasizing the struggle for status and against upper-caste domination across the board, people stress change, which they characterize as a process of "civilization" or a growth in civility (nākarīkam), and the leaving behind of a time of degradation and disgust (acinkam). "Civilization" here can 
allude to public forms of respect, standing in line, work undertaken for negotiated rates, and roles and services reframed in the idiom of the market. A disjuncture is imagined between today and the era of slavery (atimai) and untouchability (tīntämai). Christianity can be aligned with these changes without being their cause, and most did not credit the churches with changing caste practices.

The second overarching finding is that, although Dalits by and large in this way believed they were living in a changed world, without extreme caste inequality, and though they clearly expected equal treatment from modern institutions like schools and colleges, civility was not felt to be assured. Freedom from caste was uncertain. There were several reasons for this. For one thing, caste prejudice is suspected but is indiscernible; it exists unseen as a state of mind or a mental attitude and requires an attentive negotiation of social life to avoid humiliation. Likewise, Suryakant Waghmore (2018) describes a "Hindu politeness" in rural Maharashtra that might accompany "hidden disgust" and that could be withdrawn at any time to expose Dalits to violence. For another thing, poverty exposes people to caste prejudice and humiliation, just as civility and social respect bend toward money and power.

Third, although less visible in social interaction, caste is pervasive in its effects. Probing into the experiences of searching for work, education, or business opportunities reveals lives constrained in new ways by caste, reworked as the private connections and cultural capital necessary to secure jobs or other things (Mosse n.d.). Alongside assertions that things had changed, 82 percent of those asked felt caste remained an obstacle or barrier (tatai) to their family's advancement.

Fourth and finally, "inferiorized" identity is inescapable. A majority of those surveyed expected, as Dalits, to experience ill-treatment and disrespect, and could not imagine escape into casteless anonymity in rural society. Significantly, it was the poorest and women who were most led by experiences of ill treatment to try to conceal their caste, often when laboring in distant places. For example, Lily, a thirty-two-year-old Christian Dalit [Paraiyar], explains, "When we went to Chennai for bricks work, near where we worked there were céri houses [cêri meaning here both slum and Dalit "colony"]. The upper-caste people were speaking about them as inferior, so we said we were Gounders [non-Dalits]" (survey, Alapuram, Aug. 2005).

But Dalits also spoke of their fear of being discovered, and in some cases they gave this as a reason not to undertake migrant labor repeatedly for the same employers. Sixty-year-old Krishnan recalls: "We went to a village for rice harvesting, beyond Devakottai. We were working for a Kallar-caste house and hiding our caste; we did not say Paraiyar, we said we were cēniyār [weaver] people. They thought we were upper-caste people. They treated us well and gave us meals inside the house, and we were sleeping inside the house. For two harvests we went to work there. After that we didn't go again, afraid that they would come to know our caste" (ibid.). 
Many of those interviewed blamed the state for making caste inescapable for Dalits, since all have to declare "SC" status (and Hindu identity) as the condition of state support. As Catholic Dalit Arulraj said, "As soon as we are born we are baptized and at the same time the caste is written." 32

Expectations of a civility that cannot be had in face of experiences indelibly marked by caste and its harder-to-see effects produce not expressions of renewed struggle for Dalit honor (as they once did), but instead the reassertion of an ideology of casteless humanity, summed up in the aphorism, "We are human beings with one blood." The persisting power of hidden caste in shaping opportunities is met with three denials: ontological denial (caste has no truth, it is a human fabrication); temporal denial (caste is past, erased by modernity and civility); and social denial (the aspiration to castelessness). This represents a Dalit response to caste that is quite at odds with both Dalit activist assertions in the discourse of honor and Dipankar Gupta's (2005) and others' idea that identity is more important than hierarchy in modern caste politics, since it is the persistence of caste power and inequality (not to mention exposure to violence and humiliation) that removes value from identities of caste that nonetheless remain inescapable. ${ }^{33}$

The commitment to castelessness amidst the pervasive, unexpressed experience of caste determining one's life-chances is something even more evident in urban Dalit communities. Roberts explains this in his ethnographic account of Pentecostalism in the Chennai slum of Anbu Nagar (2016). Pentecostals there push castelessness further, and do not see themselves as Dalits in relation to upper castes, but rather as those with true humanity. Despite caste being central to their daily experience, it is erased from Pentecostals' accounts of themselves. Roberts infers that this is because of the shame and hurt of untouchability that shadow Dalits' flight from untouchability in the village to "mere poverty" in the city. When Anbu Nagar Pentecostals say they are casteless, they are saying, like Alapuram Dalits, that caste holds no truth. But they go further, as does Ambedkar, by insisting that caste is nothing but the denial of humanity by hoarding caste others, and that it is unique to India. Slum dwellers with shared poverty and humanity imagine themselves as humanitarian outsiders, caring and worthy of being cared for-trapped within uncaring caste India. This notion of India as a negative moral space involves a distinctive valuing of the non-Indian foreign, imagined (unrealistically it has to be said) as places and peoples of true humanity and home to loving allies. This image creates for them a corresponding "foreignness of belonging" that is found also in the utterly

\footnotetext{
${ }^{32}$ Commonly, Christian Dalits register as Scheduled Castes by officially recording Hindu identities and names.

${ }^{33}$ It is, of course, well known that Dalits hold a moral position of casteless humanity, located by today's intellectuals and leaders in various caste-evading religious and political ideologies, including identification of "Tamil" as an authentic casteless identity (see Thirumavalavan 2011). Here I am pointing to a specific change in a local Dalit discourse on caste.
} 
foreign divinity and hope beyond experience, and beyond words as in Pentecostal glossolalia. This is the precise inverse of the Hindu nationalist discourse on Christian conversion as cultural alienation and moral threat.

The Dalit aspiration to casteless humanity takes us to Dr Ambedkar's final stance: his conversion to Buddhism, not to worship different gods, or indeed any god, but as an embrace of the idea of humanity beyond the social order (Vajpeyi 2014). And as anthropologists of India, it takes us to M. N. Srinivas's emphasis on the importance of attending both to the changing nature of relations of caste, and to the distinctive terms, or discourses, through which these are represented, whether varna, Sanskritization, or now, varied forms of castelessness and claims to live "outside caste."

\section{CONCLUSION}

Caste has always generated political and scholarly controversy, but the forms that this takes today newly combine anti-caste activism with counter-claims about the irrelevance or non-existence of caste or claims to castelessness that are, in turn, viewed as the new disguise of caste power and privilege. In diaspora settings, caste is erased within an "economy of offense" in which "hurt religious sentiments" are a privilege limited to the elite (Viswanath 2016). These contentions revisit and replay older moves to enclose caste within Hinduism and the nation so as to restrict the field of social policy and law, and the contradictory figure of the Dalit Christian convert reappears as a target for ideological projections. Caste society divides between those able to sustain claims to live outside caste, which both disappears as an "inner domain" and is exteriorized to others such as its colonial inventors or subaltern purveyors, and those inescapably marked by their caste and the judgements it brings. These disputes around caste are about how "the social" is made available for public debate and especially for the law; they concern the categories of description and analysis. Postcolonial and anti-Orientalist scholarship becomes a resource in the denial of claims about caste (as an object) and its discriminatory effects, just as scholarly discourses on caste, race, or human rights are deployed in the support of such claims. As Dalits and upper castes enter epistemological debates over categories of description on opposite sides, they engage with anthropology, whose subject of enquiry - the social world - it is increasingly clear, is no longer independent or unaltered by its terms of description and debate.

\section{REFERENCES}

Ambedkar, B. R. 1979. Castes in India: Their Mechanism, Genesis and Development. In Dr. Babasaheb Ambedkar: Writings and Speeches. Vol. 1. Bombay: Education Department, Government of Maharashtra, 3-22.

Anti-Caste Discrimination Alliance. 2009. Hidden Apartheid, Voice of the Community: Caste and Caste Discrimination in the U.K. A Scoping Study. Derby: Anti-Caste Discrimination Alliance. At: http://acdauk.org.uk/pdf/Hidden\%20Apartheid\% 
20-\%20Voice $\% 20$ of $\% 20$ the $\% 20$ Community $\% 20-\% 20$ ACDA $\% 20$ Report.pdf (accessed 12 Aug. 2019).

Balagangadhara, S. N. 1994. "The Heathen in His Blindness...": Asia, the West and the Dynamic of Religion. Leiden: E. J. Brill.

Balagangadhara, S. N. 2012. Reconceptualizing India Studies. Delhi: Oxford University Press.

Chatterjee, Partha. 1993. The Nation and Its Fragments: Colonial and Postcolonial Histories. Princeton: Princeton University Press.

Clifford, James. 1997. Routes: Travel and Translation in the Late Twentieth Century. Cambridge: Harvard University Press.

Das, Veena. 2000. In Memoriam: M. N. Srinivas, 1916-1999. Seminar 487. At: http:// www.india-seminar.com/2000/487/487\%20memoriam.htm. (accessed 12 Aug. 2019).

Deshpande, Satish. 2013. Caste and Castelessness: Towards a Biography of the "General Category." Economic and Political Weekly 48, 15: 32-39.

Dhanda, Meena. 2015. Anti-Casteism and Misplaced Nativism: Mapping Caste as an Aspect of Race. Radical Philosophy 192: 33-43.

Dhanda, Meena. 2017. Casteism amongst Punjabis in Britain. Economic and Political Weekly 52, 3: 62-65.

Dhanda, Meena, David Mosse, Annapurna Waughray, David Keane, Roger Green, Stephen Iafrati, and Jessie Mundy. 2014. Caste in Britain: Experts' Seminar and Stakeholders' Workshop. Research Report 92. Manchester: Equality and Human Rights Commission. At: https:/www.equalityhumanrights.com/sites/default/files/ research-report-92-caste-in-britain-experts-seminar-and-stakeholders-workshop.pdf (accessed 12 Aug. 2019).

Dhanda, Meena, Annapurna Waughray, David Keane, David Mosse, Roger Green, and Stephen Whittle. 2014. Caste in Britain: Socio-Legal Review. Research Report 91. Manchester: Equality and Human Rights Commission. At: https:/www. equalityhumanrights.com/sites/default/files/research-report-91-caste-in-britain-sociolegal-review.pdf (accessed 12 Aug. 2019).

Dirks, Nicholas B. 2001. Castes of Mind: Colonialism and the Making of Modern India. Princeton: Princeton University Press.

Fárek, Martin, Dunkin Jalki, Sufiya Pathan, and Prakash Shah, eds. 2017. Western Foundations of the Caste System. London: Palgrave Macmillan.

Fuller, Christopher. 2016a. Anthropologists and Viceroys: Colonial Knowledge and Policy Making in India, 1871-1911. Modern Asian Studies 50, 1: 217-58.

Fuller, Christopher. 2016b. Colonial Anthropology and the Decline of the Raj: Caste, Religion and Political Change in India in the Early Twentieth Century. Journal of the Royal Asiatic Society 26, 3: 463-86.

Fuller, Christopher and Haripriya Narasimhan. 2014. Tamil Brahmans: The Making of a Middle-Class Caste. Chicago: University of Chicago Press.

Gauthaman, Raj. 2011. Dalit Culture. In K. Satyanarayana and S. Taru, eds., No Alphabet in Sight: New Dalit Writing from South India (Volume 1: Tamil \& Malayalam). New Delhi: Penguin, 151-57.

Geertz, Clifford. 1983. Local Knowledge: Further Essays in Interpretive Anthropology. New York: Basic Books.

Ghildiyal, Subodh. 2015. Government Firm on Opposing Dalit Tag for Converts. Times of India, 30 Mar. 2015. At: https://timesofindia.indiatimes.com/india/Governmentfirm-on-opposing-dalit-tag-for-converts/articleshow/46739300.cms (accessed 12 Aug. 2019).

Ghuman, Paul. 2011. British Untouchables: A Study of Dalit Identity and Education. Farnham: Ashgate. 
Government Equality Office. 2018. Caste in Great Britain and Equality Law: A Public Consultation. Government Consultation Response. GEO-00218-2018. London: Government Equalities Office. At: https://assets.publishing.service.gov.uk/government/ uploads/system/uploads/attachment_data/file/727790/Caste_in_Great_Britain_and_equality_law-consultation_response.pdf (accessed 12 Aug. 2019).

Gupta, Dipankar. 2005. Caste and Politics: Identity over System. Annual Review of Anthropology 34: 409-27.

Hacking, Ian. 1996. The Looping Effects of Human Kinds. In Dan Sperber, David Premack, and Ann James Premack, eds., Causal Cognition: A Multidisciplinary Debate. Oxford: Oxford University Press, 351-83.

Izsák-Ndiaye, Rita. 2016. Report of the Special Rapporteur on Minority Issues. Report A/HRC/31/56. Human Rights Council. New York: United Nations General Assembly. At: https://documents-dds-ny.un.org/doc/UNDOC/GEN/G16/013/73/ PDF/G1601373.pdf?OpenElement (accessed 12 Aug. 2019).

Knott, Kim. 2009. Becoming a "Faith Community": British Hindus, Identity, and the Politics of Representation. Journal of Religion in Europe 2, 2: 85-114.

Krishnan, Rajan Kurai. 2011. Caste and Religion in the Age of the Nation-State: Certain Polemical Blinders and Dalit Situations. Paper presented at the conference "Caste Out of Development," Chennai, 15 Dec. At: http://www.researchcatalogue.esrc.ac.uk/ grants/RES-062-23-2227/outputs/read/26b2cd27-703d-4048-9053-31c44d933a89 (accessed 12 Aug. 2019).

Lee, Joel. 2015. Recognition and Its Shadows: Dalits and the Politics of Religion in India. $\mathrm{PhD}$ diss., Columbia University.

Manickam, Alphonse. 2001. Les Jésuites et l'intouchabilité Au Tamil Nadu: Études Histo- Riques et Anthropologiques Sur Des Approches Longtemps Di Érées. PhD thesis, Ecole Pratique des Hautes Etudes.

Merry, Sally Engle. 2012. Anthropology and Law. In Richard Fardon et al., eds, The SAGE Handbook of Social Anthropology. Vol. 1. London: SAGE Publications, 105-20.

Metcalf, Hilary and Heather Rolfe. 2010. Caste Discrimination and Harassment in Great Britain. London: National Institute of Economic and Social Research. At: https://www.niesr.ac.uk/publications/caste-discrimination-and-harassment-greatbritain (accessed 12 Aug. 2019).

Ministry of Minority Affairs. 2009. Report on the National Commission for Religious and Linguistic Minorities. New Delhi: NCRLM. At: http://www.minorityaffairs. gov.in/sites/default/files/volume-1.pdf (accessed 12 Aug. 2019).

Mitra, Devirupa. 2016. Stung by UN Report on Caste Discrimination, India Cries Foul. The Wire, 25 Mar. At: https://thewire.in/diplomacy/stung-by-un-report-on-castediscrimination-india-hits-back (accessed 12 Aug. 2019).

Mohan, P. Sanal. 2015. Modernity of Slavery: Struggles against Caste Inequality in Colonial Kerala. New Delhi: Oxford University Press.

Mooney, Nicola. 2011. Rural Nostalgias and Transnational Dreams: Identity and Modernity among Jat Sikhs. Toronto: University of Toronto Press.

Mosse, David. 2012. The Saint in the Banyan Tree: Christianity and Caste Society in India. Berkeley: University of California Press.

Mosse, David. 2018a. Caste and Development: Contemporary Perspectives on a Structure of Discrimination and Advantage. World Development 110: 422-36.

Mosse, David. 2018b. Caste, Religion and Nation: The Relationship between Christianity and Caste Society in India and Its Misconstrual. In Surinder Jodhka and James Manor, eds., Contesting Hierarchies, Persisting Influence: Caste and Power in Twenty-First Century India. Hyderabad: Orient Blackswan, 261-90. 
Mosse, David. n.d. The Modernity of Caste and the Market Economy. Modern Asian Studies (forthcoming, Mar. 2020).

Mukta, Parita. 2000. The Public Face of Hindu Nationalism. Ethnic and Racial Studies 23, 3: 442-66.

Natrajan, Balmurli. 2012. From Jati to Samaj. Seminar 633 (May): 54-57. At: https:// www.india-seminar.com/2012/633/633 balmurli_natrajan.htm (accessed 12 Aug. 2019).

NCHT-UK. 2017. Caste, Conversion and a "Thoroughly Colonial Conspiracy." Leicester: National Council of Hindu Temples UK (NCHT). At: http://www.nchtuk.org/ pdfiles/caste_g_full.pdf (accessed 12 Aug. 2019).

Nesbitt, Eleanor. 1997. We Are All Equals: Young British Punjabis' and Gujaratis' Perceptions of Caste. International Journal of Punjab Studies 4, 2: 201-18.

Paramsothy, Thanges. 2018. Caste within the Sri Lankan Tamil Diaspora: Ūr Associations and Territorial Belonging. Anthropology Matters 18, 1. At: https://www.anthropologymatters.com/index.php/anth matters/article/view/496 (accessed 12 Aug. 2019).

Pariyar, Mitra. 2011. Cast(e) in Bone: The Perpetuation of Social Hierarchy among Nepalis in Britain. COMPAS Working Paper 11-85. Oxford: University of Oxford. At: https://www.compas.ox.ac.uk/2011/wp-2011-085-pariyar_social_hierarchy_nepalis_uk/ (accessed 12 Aug. 2019).

Patel, Pragna and Sukhwant Dhaliwal. 2016. Religion and Caste in the UK: Reflections on Hindu and Sikh Fundamentalist Mobilisations. In Alan Carling, ed., The Social Equality of Religion or Belief. London: Palgrave Macmillan, 150-65.

Roberts, Nathaniel. 2016. To Be Cared For: The Power of Conversion and Foreignness of Belonging in an Indian Slum. Berkeley: University of California Press.

Rodrigues, Valerian, ed. 2002. The Essential Writings of B. R. Ambedkar. New Delhi: Oxford University Press.

Shah, Prakash. 2015. Against Caste in British Law: A Critical Perspective on the Caste Discrimination Provision in the Equality Act 2010. London: Palgrave Macmillan.

Shah, Prakash. 2017. Orientalism, Multiculturalism, and Identity Politics: Hindus and the British Caste Law. Quaderni Di Diritto e Politica Ecclesiastica 10, 4: 111-26.

Simpson, Edward. 2016. Is Anthropology Legal? Earthquakes, Blitzkrieg, and Ethical Futures. Focaal 74 (Jan.): 113-28.

Sontheimer, Günther-Dietz and Hermann Kulke, eds. 2001. Hinduism Reconsidered. Delhi: Manohar.

Srinivas, M. N. 1976. The Remembered Village. Berkeley: University of California Press.

Srinivas, M. N. 1995. Social Change in Modern India. Delhi: Orient Blackswan.

Subramanian, Ajantha. 2015. Making Merit: The Indian Institutes of Technology and the Social Life of Caste. Comparative Studies in Society and History 57, 2: 291-322.

Sutton, Deborah Ruth. 2018. "So Called Caste": S. N. Balagangadhara, the Ghent School and the Politics of Grievance. Contemporary South Asia 26, 3: 336-49.

Takhar, Opinderjit Kaur. 2017. British Legislation against Caste-Based Discrimination and the Demand for the Sunset Clause. Contemporary South Asia 25, 3: 301-16.

Tejani, Shabnum. 2008. Indian Secularism: A Social and Intellectual History, 1890-1950. Bloomington: Indiana University Press.

Thirumavalavan, Thol. 2011. Only Caste-Annihilating Tamil Nationalism Shall Uproot Hindutva. In K. Satyanarayana and S. Tharu, eds., No Alphabet in Sight: New Dalit Writing from South India. New Delhi: Penguin, 319-24.

Thorat, Sukhadeo, Ajaya K Naik, and Nitin Tagade. 2016. Prejudice against Reservation Policies: How and Why?' Economic and Political Weekly 51, 8: 61-69. 
Vajpeyi, Ananya. 2014. B. R. Ambedkar: The Life of the Mind and a Life in Politics. Lecture presented at the Library of Congress, Washington D.C., 2 Dec. At: https:// www.youtube.com/watch?reload =9\&v = btfwqET4vg0 (accessed 12 Aug. 2019).

Vertovec, Steven. 2000. The Hindu Diaspora: Comparative Patterns. New York: Routledge.

Viswanath, Rupa. 2013. The Emergence of Authenticity Talk and the Giving of Accounts: Conversion as Movement of the Soul in South India, ca. 1900. Comparative Studies in Society and History 55, 1: 120-41.

Viswanath, Rupa. 2014. The Pariah Problem: Caste, Religion, and the Social in Modern India. New York: Columbia University Press.

Viswanath, Rupa. 2016. Economies of Offense: Hatred, Speech, and Violence in India. Journal of the American Academy of Religion 84, 2: 352-63.

Vithayathil, Trina. 2018. Counting Caste: Censuses, Politics, and Castelessness in India. Politics \& Society 46, 4: 455-84.

Waghmore, Suryakant. 2018. From Hierarchy to Hindu Politeness: Caste Atrocities and Dalit Protest in Rural Marathwada. In James Manor and Surinder Jodhka, eds., Contested Hierarchies, Persisting Influence: Caste and Power in Twenty-First Century India. Hyderabad: Orient Blackswan, 111-39.

Waughray, Annapurna. 2010. Caste Discrimination and Minority Rights: The Case of India's Dalits. International Journal on Minority and Group Rights 17: 327-53.

Waughray, Annapurna. 2014. Capturing Caste in Law: Caste Discrimination and the Equality Act 2010. Human Rights Law Review 14, 2: 359-79.

Waughray, Annapurna. 2016. Book Review: Prakash Shah, against Caste in British Law: A Critical Perspective on the Caste Discrimination Provision in the Equality Act 2010. South Asia Research 36, 3: 409-13.

Waughray, Annapura. n.d. Capturing Caste in Law: The Legal Regulation of Caste Discrimination. New York: Routledge (forthcoming 2020).

Waughray, Annapurna and Meena Dhanda. 2016. Ensuring Protection against Caste Discrimination in Britain: Should the Equality Act 2010 Be Extended? International Journal of Discrimination and the Law 16, 2-3: 177-96.

Waughray, Annapurna and David Keane. 2017. CERD and Caste-Based Discrimination. In Annapurna Waughray and David Keane, eds., Fifty Years of the International Convention on the Elimination of All Forms of Racial Discrimination: A Living Instrument. Manchester: University of Manchester Press, 121-49.

Zavos, John. 2012. Hinduism. In Linda Woodhead and Rebecca Catto, eds., Religion and Change in Modern Britain. Abingdon: Routledge, 121-31.

Zavos, John. 2015. Small Acts, Big Society: Sewa and Hindu (Nationalist) Identity in Britain. Ethnic and Racial Studies 38, 2: 243-58. 
Abstract: Caste has always generated political and scholarly controversy, but the forms that this takes today newly combine anti-caste activism with counter-claims that caste is irrelevant or non-existent, or claims to castelessness. Claims to castelessness are, in turn, viewed by some as a new disguise for caste power and privilege, while castlessness is also an aspiration for people subject to caste-based discrimination. This article looks at elite claims to "enclose" caste within religion, specifically Hinduism, and the Indian nation so as to restrict the field of social policy that caste applies to, to exempt caste-based discrimination from the law, and to limit the social politics of caste. It does so through a comparative analysis of two cases. The first is the exclusion of Christian and Muslim Dalits - members of castes subordinated as "untouchable"-from provisions and protections as Scheduled Castes in India. The other case is that of responses to the introduction of caste into anti-discrimination law in the UK. While Hindu organizations in the UK reject "caste" as a colonial and racist term and deploy postcolonial scholarship to deny caste discrimination, Dalit organizations, representing its potential victims, turn to scholarly discourse on caste, race, or human rights to support their cause. These are epistemological disputes about categories of description and how "the social" is made available for public debate, and especially for law. Such disputes engage with anthropology, whose analytical terms animate and change the social world that is their subject.

Key words: caste, religion, Hinduism, India, UK equality law, Dalit activism, anthropology 